\title{
A Summary of the Status Quo of Scientific Research Team Construction in Higher Vocational Colleges in China
}

\author{
WANG Di ${ }^{1, \mathrm{a}}$ \\ ${ }^{I}$ Research Department of Beijing Information Technology college, Chao Yang, Beijing, China \\ awangd@bitc.edu.cn
}

\begin{abstract}
The scientific research level of higher vocational colleges is one of the important indicators for evaluating the core competitiveness of the school. The construction of scientific research teams in higher vocational colleges is an important factor that affects the level of scientific research in schools. There are few researches on higher vocational scientific research teams in our country, and there is a large gap in the amount of literature, which is a common problem that needs to be solved at this stage. After sorting out the relevant literature, it is found that the construction of higher vocational scientific research teams is mainly reflected in four aspects: the fuzzy positioning of higher vocational scientific research work, the insufficient attention to higher vocational scientific research work, the unreasonable management system of higher vocational scientific research team, and the problem of scientific research team. Talent is weak.
\end{abstract}

Keywords: higher vocational colleges, scientific research team, problem summary, Scientific research orientation

\section{FOREWORD}

As an essential part of higher education in China, the higher vocational colleges also undertake the tasks of scientific and technological innovation and technical services. Along with the development of the era, the scientific research in higher vocational colleges gradually becomes an important indicator in core competitiveness assessment. At current stage, scientific research in China's higher vocational colleges has a weak foundation, such as insufficient research funds, shortage of talents and lack of institutional mechanism, etc. To cultivate scientific research teams is an effective approach to promote the comprehensive capacity of higher vocational colleges in scientific research as soon as possible.

There are a lot of research data concerning the building of scientific research team in China's universities, but there is little research on building scientific research teams in higher vocational colleges. 1518 literatures are searched by inputting the keyword of "college scientific research team" in CNKI. 192 literatures are searched by inputting the keyword of "higher vocational scientific research team". As regards the research data of scientific research teams in universities and higher vocational colleges, the literature quantity of higher vocational colleges is about $9 / 10$ less than that of universities. Therefore, the research and establishment of scientific research teams in higher vocational colleges is a prevailing and urgent problem at the current stage.

\section{VAGUE POSITIONING OF SCIENTIFIC RESEARCH WORK IN HIGHER VOCATIONAL COLLEGES}

Higher vocational colleges have the dual properties of higher education and vocational education. Their teaching must be employment-oriented, focusing on cultivating the student's vocational capacity. Higher vocational colleges aim to supply high-quality professional talents to enterprises. Meanwhile, higher vocational colleges also share the basic functions with universities, i.e., scientific research. However, the scientific research of higher vocational colleges has not been clearly defined, as shown in the following aspects:

\subsection{Blindly imitate universities' scientific research management mode}

As higher vocational colleges do not build a systematic scientific research mechanism and they 
blindly imitate the scientific research management mode of universities, the false positioning was formed in the system. The reason lies in schools' incorrect knowledge of educational positioning and failure to fully reflect the features of vocational education. The scientific research work of higher vocational colleges must be tailored to the reality of high vocational education in China, and the foundational disciplines and basic theory problem of disciplines should not be the focus of the research.

Some teachers in higher vocational colleges also make mistake by comparing with universities. They sense the strong scientific research capacity of universities, and they are feared due to the little achievement higher vocational colleges have made in research project declaration. They formed the false cognition that teachers in higher vocational colleges are incapable of scientific research comparing with their counterpart in universities, combining with the poor quality of students in higher vocational colleges.

\subsection{Confuse the functions of scientific research teams and teaching teams}

The higher vocational colleges cannot correctly define the relationship between teaching and scientific research. They manage the teaching teams as they are managing scientific research teams, and manage teaching research achievements as they are managing scientific research achievements. There exists the conventional idea of highlighting teaching and neglecting scientific research in some scientific research departments. They focus on carrying out research in teaching reform and discipline construction, but neglect the guidance, coordination, organization and construction of scientific research teams to carry out academic research and technical services. They seldom organize scientific research teams to cooperate with enterprises so as to serve the community they are in. They also fail to help teachers coordinate and solve the conflicts between scientific research and teaching.

\subsection{The scientific research doesn't have defined objectives, and long-term planning is required}

Most higher vocational colleges lack long-term planning when making scientific research, and their scientific research structure is still irrational, and their objectives are ill-defined. This is mainly reflected in the following aspects. They highlight project declaration quantity, neglect research quality, and the conclusion quantity and quality of scientific research projects still need to be promoted; they lack projects of technology applications from enterprises, which do not comply with the education features of higher vocational colleges. The scientific research projects cannot contribute to the regional economic and social development, and the fields of achievement conversion are narrow. Therefore, the scientific research is of low quality, the content is duplicate, and new breakthrough can hardly be made.

Higher vocational colleges lack the cultivation planning of scientific research talents, and teachers also lack the scientific research content of their own occupational development planning. Colleges lack the scientific research content of post training, exemplary deed commendation, and occupation planning for new teachers, so the talent construction of scientific research teams is not consistent.

Higher vocational college teachers also pursue speed rather than quality when selecting research projects. They do not emphasize the discipline value and their own research background of projects, blindly follow the trend, so the scientific research work is not consistent and systematic, lacks stable research content and direction. The breakthrough cannot be made, so they lack competitive advantage.

\section{THE SCIENTIFIC RESEARCH IN HIGHER VOCATIONAL COLLEGES IS UNDEREMPHASIZED}

During fast development of higher vocational education in the past three decades, the scientific research in higher vocational colleges is still underemphasized, and the scientific research teams are not getting the respects they deserve.

The position of higher vocational scientific research work is closely associated with the development of higher vocational colleges. One higher vocational college is formed by merging several secondary vocational schools, but secondary vocational schools do not have the experience in scientific research, so colleges neglect the scientific research. Compared with universities, higher vocational colleges' negligence of scientific research work is reflected in the following aspects:

\subsection{The scientific research management department is underemphasized}

The scientific research management departments or organizations are not placed in the proper position throughout the whole school. Many higher vocational colleges do not set up a scientific research division when they were founded, and it is affiliated to the office of educational administration if it is established. Although some scientific research organizations are established for a long time, they do not carry out substantial research. The scientific research division is emptily set or merely exists nominally among the administration departments. The scientific research division is incorporated into the second-category office for management. Its outlay is far less than that of other departments. It is also understaffed. 2 or 3 persons may need to accomplish the dual task of administration and research, and the personnel quality and skill are also insufficient. 


\subsection{The importance is not attached to scientific researchers}

The scientific researchers are not respected and emphasized. Higher vocational colleges highlight teachers' expertise and practice ability, excessively highlight occupational skill contests. If teachers are specialized in scientific research, they may be marginalized by the teaching faculties, which will affect their personal occupational development. Therefore, the scientific research is regarded as an irrelevant business and a non-compulsory activity. Some department heads or principals become an executor of strenuous education teaching activities such as teaching administration and academic management, etc. These key teachers lack the energy in the scientific research. Colleges also lack the mandatory index of scientific research in teachers' performance examination. If any, the proportion of scientific research is not appropriate

\subsection{Insufficient scientific research funds}

The scientific research projects of higher vocational colleges mainly aim at providing technical services. The demands focus on innovating applied technology and upgrading and transforming products, which require a large sum of scientific research fund. As the scientific research strength of higher vocational colleges is weak, the research funds are mainly raised by colleges. The amount is small, which cannot meet the requirement of scientific and technological innovation for enterprises. Therefore, the emphasis of scientific research of higher vocational colleges at the current stage is the research on education and teaching. Due to lack of sufficient research fund it is apparently impossible for colleges to attract ideal resources through horizontal subjects, or incorporate them into scientific teams of colleges.

\section{IRRATIONAL MANAGEMENT SYSTEM OF SCIENTIFIC RESEARCH TEAM IN HIGHER VOCATIONAL COLLEGES}

\subsection{The improvement of scientific research teams lacks policy support}

Firstly, the Ministry of Education does not issue the guidance advice on scientific research team improvement in higher vocational colleges. Secondly, provinces, cities and autonomous regions do not pay enough attention to the scientific research in higher vocational colleges. Finally, due to a lack of policy support of the authorities at higher levels, higher vocational colleges also do not have relevant policies. To improve the teaching team of higher vocational colleges, the national and regional governments and colleges should pay enough attention, issue relevant policy documents, and select excellent teaching teams and provide incentives for them, such as the national-level teaching team selection organized by the Ministry of Education, the regional teaching team selection organized by provincial and municipal education departments, and school-level teaching team selection organized by higher vocational colleges and so on. Comparatively, the scientific research teams of higher vocational colleges have neither fund support nor honor awards, which lags far behind that of the teaching team.

\subsection{Scientific research team improvement lacks examination and assessment}

In terms of management, the scientific research teams of higher vocational colleges lack effective supervision and assessment mechanisms, and clear team accountability and awarding systems. As usual, the interim examination and conclusion assessment of scientific research subject are used for supervising and assessing teams, and project approval fund, supporting outlay and personal academic achievement awards are used as the final award scientific teams and their members. No special award is granted to the heads of scientific research teams, so they lack enthusiasm. Higher vocational colleges also do not issue independent punishment policies for scientific research teams. After approval of projects, they do not carry out interim examination, and even do not take punishment measures for failure to finish projects on time, which affects the benign development of scientific research of higher vocational colleges.

From the perspective of teachers' examination, some higher vocational colleges do not incorporate scientific research into teachers' rigid assessment system. Scientific research does not mean a compulsory task for them. They only do scientific research if they want, so it does not serve as work pressure and impetus for teachers. Even if some higher vocational colleges incorporate the results of scientific research into teachers' assessment system, there is no effective reward and punishment system. Hence the assessment system cannot effectively guide the scientific research. Compared with universities, higher vocational colleges' awards in scientific research work vary greatly, and the award amount and range is still insufficient. Sometimes, teachers would rather take more lessons and do part-time job by teaching outside the colleges than engage in scientific research. Furthermore, schools do not establish a punishment system for teachers who do not undertake scientific research projects, so scientific research cannot play the role of awarding exemplary deeds and encouraging those who fall behind.

\subsection{Scientific research team improvement lacks platform support}

Exchange platforms are still needed to build a scientific research team in higher vocational colleges. Firstly, an exchange platform is needed for the scientific research management personnel. Their exchange with 
enterprises and their counterpart in other higher vocational colleges is insufficient, resulting in their deficient scientific research management mode and ideas. Their narrow outlook has confined their thoughts. Secondly, higher vocational colleges lack an innovative platform. $70 \%$ enterprises believe that during the cooperation of production, teaching and research, they don't have the information to seek cooperation with higher vocational colleges through platforms, and there is no suitable approach to solve the technical problems in production. $95 \%$ scientific research teams believe that their colleges shall strengthen the construction of scientific research innovation platforms.

\section{WEAK TALENT STRENGTH OF SCIENTIFIC RESEARCH TEAMS}

\subsection{The attachment of scientific research teams is insufficient}

Scientific research teams require an inter-disciplinary team head. This is the key to establish academic research teams. To be the heads of the academic research team, one needs to have high academic research capability and scientific research innovation spirit, and he should have a strong communication ability, organization ability, coordination ability and cooperation spirit. However, some experts and professors in the higher vocational colleges at the current stage do not meet these requirements. The scientific research teams in some colleges adopt the management mode of teaching research teams. The team heads lack management experience and ability of scientific research. They cannot fully mobilize the academic resources of members and make use of their discipline advantages to conduct scientific research. In case any problem arises, they cannot guide teachers and coordinate them to solve the conflicts between scientific research and teaching, and they cannot rationally distribute the research task workload among members. According to an investigation of scientific research personnel in 10 private higher vocational colleges in Zhejiang Province, Zhu Xiaofeng and Gao Chuangkuan found that $54 \%$ respondents believed that their teaching tasks were too tiresome, which serves as the primary reason hindering their scientific research. The poor coordination of team heads causes not smooth internal communication in teams, excessively free activity of members, insufficient cooperation and failure to efficiently make use of space and equipment, etc.

\subsection{Irrational structure of scientific research team personnel}

The research directions of higher vocational colleges are remarkably different from those of universities. Research in higher vocational is mainly applicationoriented. Scientific research in higher vocational colleges aim to provides enterprises with technical support, innovation and promotion on the basis of talent cultivation. Therefore, the talent structure of scientific research teams shall be tailored to this characteristic of higher vocational colleges, reflecting the diversity rather than linear features so as to integrate production with teaching activities. As for talent structure, the interaction with industries is seldom taken into account at the beginning of building scientific research teams in most higher vocational colleges, and they are simply conducted by individual teachers inside colleges. With such a team structure, it is easy for scientific research teams to have a negative mindset, resulting in the failure of the technical conversion of scientific research achievements. Eventually, the scientific research is only made out of interests and the wanting of professional titles.

\subsection{Weak Cohesiveness of scientific research teams}

Disciplines and majors in higher vocational colleges are mutually independent. They don't have much exchange and cooperation between them. Teachers' individual research prevails, so the research is only made out of their personal interests and not for solving application problems. Even though the project research is made by teams, the teams are temporarily organized by some or dozens of teachers. Most of the research is still finished by one single individual. Other members do not partake actually. The independent personal research achievements differ greatly with those of team research. In essence, teachers in higher vocational colleges lacks in the cohesiveness of scientific research teams. They simply confound research teams with research groups, and believe that the research groups are temporarily established for project research. It is even harder to establish a scientific research team with special features.

\section{CONCLUSION}

In conclusion, as the scientific research capacity of China's higher vocational colleges is relatively weak, there are few research literatures on relevant management systems, which are far less than those of universities. Through analysis of relevant literatures, it is found that the problems of scientific research team improvement in higher vocational colleges include vague positioning of scientific research, insufficient emphasis in scientific research, irrational management system of scientific research teams and weak talent force of scientific research teams. It is suggested to improve their management systems, strengthen the building of scientific research teams, and gradually promote the scientific research level in vocational colleges according to these four aspects. 


\subsection{Redefine the position of scientific research in higher vocational colleges}

The problem whether to make scientific research has caused a furious debate in China's education community in 2009. Xiong Bingqi believes that the unique function of higher vocational colleges is cultivating talents rather than making scientific research. Higher vocational colleges shall put more effort into teaching research rather than scientific research. Ouyang Xin proposed the repositioning of scientific research in higher vocational colleges through in-depth analysis of the debate. He believed that research should focus on application on the basis of vocation and practice.

The positioning of scientific research in higher vocational colleges must be different from that of universities, and it shall highlight vocation. The scientific research targets of higher vocational colleges shall highlight applied knowledge rather than theoretical knowledge, emphasize technical achievement conversion rather than research and development, solve the technical reform problems of enterprise production rather than research of fundamental theories, and it shall originate from practice and aim to be applied in practice. The scientific research capacity of higher vocational colleges is weak. Some higher vocational colleges are upgraded from secondary vocational schools. It is a fact that the capacity of teachers' scientific research is insufficient. Therefore, the scientific research direction shall be selected on the basis of the colleges' current excellent majors and the teaching reform. Major breakthrough shall be made by solving the current teaching bottlenecks to research objectives. The colleges' own major advantages shall be highlighted, and both teaching achievements and scientific research achievements shall be realized. The priority development direction of scientific research in higher vocational colleges shall be redefined so as to promote scientific research yield and explore a complete and perfect scientific research management mode.

\subsection{Promote the position of scientific research work in higher vocational colleges}

Vocational Education Law of the People's Republic of China, Higher Education Law of the People's Republic of China and Teachers Law of the People's Republic of China define the legal position of scientific research of higher vocational colleges and teachers in China, which is protected and encouraged by laws.

The higher vocational education aims to cultivate high-level vocational professional talents. The talent cultivation goal may not be limited to provide practical skills for students and equip them for future career. It shall also help them to have creative skills for technical innovation. This is the key indicator in which higher vocational education differs from secondary vocational education. The integration of production, teaching and research is an inevitable task of higher vocational colleges. However, the research is neglected in most higher vocational colleges. Colleges shall redefine the scientific research, and the research achievement shall become the key link of cultivating students and serving enterprises. While the enterprise technical reform is promoted, the advanced research achievement is introduced into teaching so that the teaching mode integrating with production, teaching and research can become a reality.

\subsection{Establish and perfect scientific research team management systems}

The college-level awarding system shall be established for scientific research. At first, the teachers' scientific research assessment system shall be established, and the more awards shall be granted for scientific research. The scientific research shall be incorporated into teachers' rigid examination index system, so scientific research will become teachers' compulsory task, serving as working pressure, impetus and guidance to them.

The college-level scientific research team assessment system shall be established. The teaching teams of higher vocational colleges are better managed than scientific research team. It can be used as reference to establish a set of scientific research team awarding system so as to provide both spiritual and physical support. As regards the scientific research project management, an effective supervision and assessment mechanism shall be established, and the team accountability system and award and punishment methods shall be improved. Those who cannot pass interim examination or cannot finish projects after approval of projects shall be punished so as to facilitate the sound development of scientific research. A special fund for scientific research awards shall be set up, the yield rate of scientific research achievements and individual contribution rate shall be taken as the only basis for rewarding, and no egalitarian shall be adopted in the team assessment system.

The head of scientific research team shall be specially cultivated. Scientific research teams require an interdisciplinary team head, which is the key to establish academic research teams. To be the head of scientific research team, one need to have a high academic research capability, innovative spirit, strong communication ability, organization ability, coordination ability and cooperation spirits. The team heads' scientific research management experience and ability shall be specially cultivated so that they can fully mobilize the academic resources of members and make full use of the advantages of their disciplines. In case of any problem, the heads shall actively coordinate members' conflicts between scientific research and teaching and rationally distribute the research workload among members. 
When establishing a proper the scientific research team system, it shall also be fully implemented. The objective laws, talents and knowledge of scientific research shall be respected. With scientific research teams as the core, the scientific research level of China's higher vocational colleges shall be gradually promoted, and the high-quality vocational education mode with Chinese characteristics shall be established.

\section{PROJECT FUND}

This paper is the periodic achievement for the 2019 project Teaching Quality Governance Framework and Analysis Model Research in Vocational College from the Perspective of Collaborative Governance in Beijing Information Technology College (XY-YN-13-201924)

\section{REFERENCES}

[1] Liu, J.W. (2014) On The Dilemma And Outlet Of Scientific Research Orientation In Higher Vocational Colleges. J. Science And Technology Management Research, 12:76-79

[2] Luo, J.F. (2014) Innovation And Construction Of Scientific Research Team In Higher Vocational Colleges In The New Development Period J. Education And Occupation, 12:32-34

[3] Zhang, S. (2014) Dislocation Development: The Orientation And Outlet Of Higher Vocational Research. J. Science And Technology Of Chinese Universities, 09:77-79

[4] Xiao, Z.F.(2014) Current Situation And Countermeasures Of Scientific Research Team Construction In Higher Vocational Colleges. J. Education And Occupation, 02:37-38
[5] Wang, H.F. (2014), Preliminary Study On The Construction Mode Of Scientific Research And Innovation Team In Higher Vocational Colleges, J. Education And Occupation, 10:85-87

[6] Zhu, X.F, Gao, C.K. (2018), Investigation And Research On Scientific Research Status Of Private Higher Vocational Colleges. J. Educational Theory And Practice, 21:36-38

[7] Xiong, B.Q. (2009) The Real "Short Board" Of Higher Vocational Education Is Not Scientific Research, But Teaching Research. J. Vocational Technology, 12:01

[8] Ou, Y.X, Huang, C.(2016) New Discussion On Scientific Research Status And Optimization Path Of Vocational Colleges. J. China Education Journal, S1:153-155

[9] Hu, H.L, Shang, Y.F. (2017) Difficulties And Countermeasures Of Innovative Scientific Research Team Construction In Local Higher Vocational Colleges. J. Journal Of Yueyang Vocational And Technical College, 06:44-47

[10] Xu, H.C, Li, Y., Yao, Y.(2019) An Analysis Of The Influencing Factors And Mechanism Innovation Of Scientific Research Team Construction In Higher Vocational Colleges. J. Time Economy And Trade, 28:44-47

[11] Han, C.B. (2012) Thinking And Practice Of Scientific Research Team Construction In Higher Vocational Colleges, J. Science And Technology Management Research, 20:120-124 